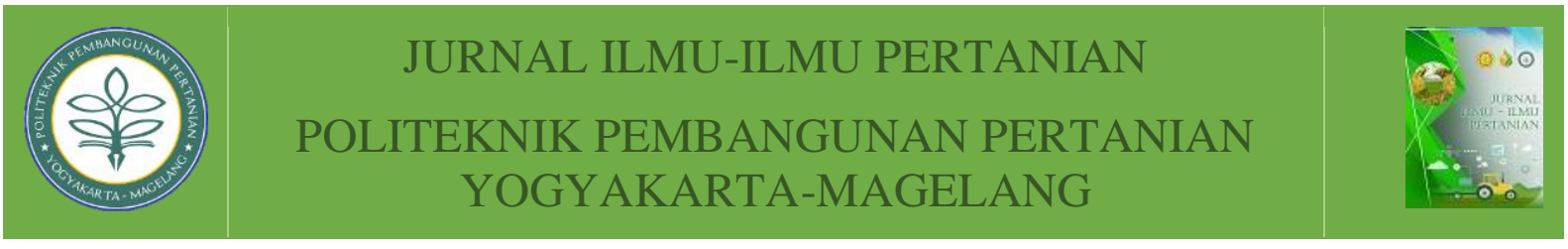

\title{
SIKAP PETANI TENTANG KEBERLANJUTAN USAHATANI CABAI MERAH DI KELURAHAN SUMBERHARJO KAPANEWON PRAMBANAN KABUPATEN SLEMAN
}

\author{
Miftakhul Arifin ${ }^{1}$, Agus Wartapa ${ }^{2}$ \\ ${ }^{1}$ Politeknik Pembangunan Pertanian Yogyakarta Magelang, Yogyakarta, 55167 \\ ${ }^{2}$ Politeknik Pembangunan Pertanian Yogyakarta Magelang, Yogyakarta, 55167
}

Received

Accepted

Published

Copyright Notice

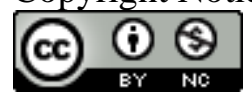

: March $11^{\text {th }}, 2021$

: April $12^{\text {th }}, 2021$

: June $17^{\text {th }}, 2021$

: Authors retain copyright and grant the journal right of first publication with This work is licensed under a Creative Commons Attribution-Non Commercial 4.0 International License.

ABSTRAK: Penelitian ini bertujuan untuk mengetahui (1) Sikap petani terhadap keberlanjutan usahatani cabe merah, (2) Variabel-variabel yang menjadi pertimbangan sikap petani terhadap keberlanjutan usahatani cabe merah, dan (3) Tingkat keberlanjutan usahatani cabe merah menurut sikap para petani di Desa Sumberharjo, Kecamatan Prambanan. Penelitian ini merupakan penelitian deskriptif kuantitatif. Responden yang terlibat dalam penelitian ini yaitu petani sebanyak 28 orang yang ditentukan secara purposive sampling yaitu petani yang menanam cabe merah pada musim tanam 2018/2019 di desa Sumberharjo, Kecamatan Prambanan. Data penelitian diambil menggunakan metode kuesioner. Analisis data dilakukan secara deskriptif. Hasil penelitian yaitu (1) Sebagian besar petani di Desa Sumberharjo, Kecamatan Prambanan memiliki sikap ingin melanjutkan usahatani cabe merah, dan terdapat sebagian yang ragu-ragu untuk melanjutkan usahatani cabe merah, (2) Variabel-variabel yang meliputi ekonomi, sosial, kelembagaan dan teknologi disikapi sebagai pendorong untuk melanjutkan usahatani cabe merah, sementara variable ekologi disikapi ragu-ragu untuk melanjutkan usahatani tersebut, (3) Tingkat keberlanjutan usahatani cabe merah yang diukur menggunakan indeks keberlanjutan usahatani memberikan keputusan sangat berkelanjutan sebagian besar variabel, kecuali variable ekologi, tetapi secara keseluruhan memberi keputusan cukup berkelanjutan.

Kata Kunci : Sikap, Keberlanjutan, Usahatani Cabe Merah.

ABSTRACT: This study aims to determine (1) the attitude of farmers towards the sustainability of red chili farming, (2) the variables that are considered by the farmers' attitudes towards the sustainability of red chili farming, and (3) the level of sustainability of red chili farming according to the attitudes of farmers in Sumberharjo Village. Prambanan District. This research is quantitative descriptive. Respondents involved in this study were 28 farmers who 
were determined by purposive sampling, namely farmers who planted red chilies in the 2018/2019 planting season in Sumberharjo village, Prambanan District. The research data was taken using a questionnaire method. Data analysis was carried out descriptively. The results of the study were (1) Most of the farmers in Sumberharjo Village, Prambanan District had the attitude of wanting to continue farming red chilies, and there were some who were hesitant to continue farming red chilies, (2) variables which included economic, social, institutional and technology is considered as an impetus for continuing red chili farming, while ecological variables are hesitant to continue the farming, (3) The level of sustainability of red chili farming as measured using the farming sustainability index gives very sustainable decisions for most of the variables, except for ecological variables, but the whole gave a fairly sustainable decision.

Keywords : Attitude, Sustainability, Serve Red Chilies.

\section{PENDAHULUAN}

Dalam pengembangan komoditas cabe merah tidak lepas dari berbagai permasalahan yang dihadapi petani. Beberapa permasalahan yang sering dikeluhkan para petani cabe merah antara lain bahwa komoditas cabe merah sangat fluktuatif dalam pemasaran, baik yang menyangkut harga dan juga permintaan pasar. Fluktuasi harga sangat ditentukan antara lain adanya banyak sedikitnya stok produksi, dan fluktuasi permintaan tergantung tingkat kebutuhan masyarakat. Pada keadaan tertentu ketika stok produksi banyak sementara permintaan sedikit maka harga akan jatuh, sebaliknya bila stok produksi sedikit sementara permintaan tinggi maka harga bisa tinggi.

Disamping adanya fluktuasi pada pemasaran, juga hal teknis yang menentukan keberhasilan bertanam cabe merah. Luas penanaman cabe merah pada era ini tidak ditentukan adanya musim, karena kebutuhan cabe tidak ditentukan adanya musim. Dengan demikian maka banyak petani menanam cabai di luar musim. Konsekuensi dari keadaan ini maka petani harus menggunakan teknologi yang dapat diadopsi untuk menanam cabe di luar musim. Bagi petani yang kurang menguasai teknologi budidaya tanam cabe diluar musim akan banyak mengalami kegagalan, sementara petani yang menguasai teknologi dan mampu menyediakan saprodi bertanam cabe di luar musim akan mengalami keberhasilan.

Disamping kondisi umum seperti di atas, juga permasalahan kondisi lahan pertanian di daerah Prambanan. Daerah Prambanan merupakan salah satu daerah pinggiran kota Yogyakarta, yang merupakan daerah urban. Kondisi lahan di daerah pinggiran kota mempunyai berbagai permasalahan yang menyangkut kondisi teknis, ekonomi dan sosial. hal ini menjadi fenomena dan informasi yang begitu mudah diketahui para petani. Kondisi demikian akan menjadi pertimbangan para petani dalam berusahatani cabai yang memakan biaya yang begitu besar.

Dalam teori stimulus - respon, maka berbagai permasalahan usahatani cabe merah menjadi stimulus bagi petani, sehingga memberikan respon yang berbeda-beda bagi setiap petani. Bagi petani yang merasa mampu dan berhasil mengatasi keadaan yang berhubungan dengan faktor- faktor produksi biasanya akan melanjutkan usahataninya. Dipihak lain bila banyak mengalami kegagalan maka biasanya akan berhenti atau berhenti sementara untuk belajar untuk mengatasi permasalahan yang dihadapi dalam berusahatani.

Tindakan petani untuk melanjutkan atau berhenti bertani sangat dipengaruhi 
sikap petani yang merupakan respon ketika menghadapi stimulus yang dipahami. Sikap merupakan respon perilaku mental dari hasil pertimbangan dalam pengambilan keputusan sesuai pengalaman dan pengetahuan yang dihasilkan dari interpretasi berupa persepsi yang juga merupakan permulaan dari respon hasil pemahaman dari stimulus.

\section{Pengertian Sikap}

Para ahli berbeda pendapat mengenai batasan sikap. Diantara beberapa ahli telah mengemukakan beberapa batasan antara lain:

a) Sikap adalah evaluasi umum yang dibuat manusia terhadap dirinya sendiri, orang lain, objek atau isu. (Petty, Cocopio, 1986 dalam Azwar S., $2000: 6$ ).

b) Sikap adalah merupakan reaksi atau respon seseorang yang masih tertutup terhadap suatu stimulus atau objek (Notoatmojo, 1997 : 130).

c) Sikap adalah pandangan-pandangan atau perasaan yang disertai kecenderungan untuk bertindak sesuai sikap objek tadi (Heri Purwanto, 1998 :62).

Dari pendapat-pendapat tersebut dapat dikemukakan secara umum bahwa "Sikap adalah keadaan dalam diri manusia yang menggerakkan untuk bertindak, menyertai manusia dengan perasaan- perasaan tertentu di dalam menanggapi objek dan terbentuk atas dasar pengalaman-pengalaman.

Struktur sikap terdiri atas 3 komponen yang saling menunjang yaitu (Azwar S., 2000: 23):

a) Komponen kognitif merupakan representasi apa yang dipercayai oleh individu pemilik sikap.

b) Komponen afektif merupakan perasaan yang menyangkut aspek emosional.

c) Komponen konatif merupakan aspek kecenderungan berperilaku tertentu sesuai dengan sikap yang dimiliki oleh seseorang.

Sikap dapat pula bersifat positif dan dapat pula bersifat negatif (Heri Purwanto, 1998 : 63): Sikap positif kecenderungan tindakan adalah mendekati, menyenangi, mengharapkan objek tertentu. Sikap negatif terdapat kecenderungan untuk menjauhi, menghindari, membenci, tidak menyukai objek tertentu.

Pengukuran sikap dapat dilakukan dengan menilai pernyataan sikap seseorang. Pernyataan sikap mungkin berisi atau mengatakan hal-hal yang positif mengenai objek sikap, yaitu kalimatnya bersifat mendukung atau memihak pada objek sikap (pernyataan yang favourable). Sebaliknya pernyataan sikap mungkin pula berisi halhal negatif mengenai objek sikap yang bersifat tidak mendukung maupun kontra terhadap objek sikap (pernyataan yang tidak favourabel) (Alimul, 2010).

Pengukuran sikap dapat dilakukan secara langsung atau tidak langsung. Secara langsung dapat ditanyakan bagaimana pendapat/pernyataan responden terhadap suatu objek. Secara tidak langsung dapat dilakukan dengan pernyataan-pernyataan hipotesis kemudian ditanyakan pendapat responden melalui kuesioner (Notoatmodjo, 2003).

\section{Keberlanjutan Usahatani}

OECD (1993), Kay dan Alder (1999) menyebutkan beberapa kriteria yang dapat menjadi acuan pembangunan berkelanjutan, yaitu menyangkut aspek ekologi, ekonomi, sosial budaya serta hukum dan kelembagaan. Pembangunan pertanian berkelanjutan adalah bagian dari konsep pembangunan berkelanjutan yang tertuang dalam Agenda-21 hasil konferensi United Nations Conference on Environment (UNCED) tahun 1992 (IISD, 1995). Sejak 
dideklarasikan tahun 1992, sampai saat ini masih banyak para ahli yang berbeda pendapat dalam memaknai konsep pembangunan pertanian berkelanjutan. Seperti yang dikemukakan oleh ReigMartinez et. al. (2011), dalam konteks penelitian empiris, konsep pembangunan pertanian berkelanjutan masih samar dan tidak mudah dipahami.

Para ahli telah melakukan upaya penelitian yang cukup besar dengan menetapkan skala yang sesuai acuan untuk menilai keberlanjutan kerangka teoritis yang memadai untuk mengintegrasikan berbagai aspek keberlanjutan (Rao and Roger, 2006). Bhossaq et.al. (2012) menyatakan bahwa implementasi pembangunan berkelanjutan pada hakikatnya merupakan hasil interaksi dari berbagai dimensi keberlanjutan, tiga dimensi penting yang sering dijadikan acuan adalah ekonomi, sosial, dan lingkungan.

Pada umumnya, konsep pertanian berkelanjutan didasarkan kepada kerangka segitiga pembangunan berkelanjutan (environmentally sustainable development triangle) yang disampaikan oleh Munasinghe dari Bank Dunia yaitu pembangunan yang berorientasi kepada tiga dimensi keberlanjutan yang saling mendukung dan terkait yaitu dimensi ekonomi, sosial dan ekologi (Novita et al., 2012).

Menurut Kang Toery (2017), keberhasilan sebuah usaha petani di sektor pertanian bukanlah semata-mata karena faktor keberuntungan saja, tetapi ada beberapa faktor yang mempengaruhinya. Faktor tersebut dibedakan menjadi dua bagian yaitu faktor internal dan faktor eksternal yang keduanya saling mempengaruhi baik secara langsung maupun tidak langsung. Faktor internal bisa juga diartikan sebagai sifat alami petani/lahan yang keberadaanya menjiwai petani dalam melakukan usahanya, yaitu meliputi (1) Kompetensi Sumber Daya Manusia (SDM), (2) Jiwa wirausaha tani, (3) Kepemilikan lahan, dan (4) Kesuburan tanah. Faktor eksternal yang mempengaruhivkeberhasilan berusahatani meliputi: (1) Iklim/cuaca, (2) Sarana transportasi dan komunikasi, (3) Pupuk dan pestisida, dan (4) Kebijakan pemerintah.

\section{Hasil Penelitian yang Relevan}

Penelitian dari Lisa Tri Kurnia, Rosyani, dan Aulia Farida, 2018 tentang Faktor-Faktor Yang Mempengaruhi Keberlanjutan Petani Berusahatani Padi Sawah (Studi Kasus di Desa Pulau Aro Kecamatan Tabir Ulu Kabupaten Merangin). Status keberlanjutan petani mengusahakan usahatani padi sawah di Desa Pulau Aro ini dilihat dari tiga aspek yaitu aspek ekologi, aspek sosial, dan aspek ekonomi. Kesimpulan : Berdasarkan hasil penelitian yang telah dilakukan, maka dapat ditarik beberapa kesimpulan yaitu sebagai berikut ; (1) faktor-faktor yang mempengaruhi petani berusahatani padi sawah di Desa Pulau Aro terdiri dari tiga faktor yaitu; tradisi atau kebiasaan, luas lahan dan kebijakan pemerintah, (2) secara keseluruhan yaitu aspek ekologi, aspek sosial, dan aspek ekonomi status keberlanjutan usahatani padi sawah di Desa Pulau Aro Kecamatan Tabir Ulu Kabupaten Merangin berada dalam kategori kurang.

Dengan kondisi permasalahan dan teori diatas maka penelitian ini dapat dirumuskan masalahnya yaitu: (1) Bagaimanakah sikap petani terhadap keberlanjutan usahatani cabai merah di Desa Sumberharjo, Kecamatan Prambanan? (2) Variabelvariabel apakah yang menjadi pertimbangan sikap petani untuk keberlanjutan berusahatani cabai merah di Desa Sumberharjo, Kecamatan Prambanan? (3) Seberapa tinggi tingkat keberlanjutan berusahatani cabai merah 
menurut sikap para petani di Desa Sumberharjo, Kecamatan Prambanan.

Tujuan penelitian ini adalah untuk mengetahui: (1) Sikap petani terhadap keberlanjutan usahatani cabe merah di Desa Sumberharjo, Kecamatan Prambanan, (2) Variabel-variabel yang menjadi pertimbangan sikap petani terhadap keberlanjutan usahatani cabe merah di Desa Sumberharjo, Kecamatan Prambanan, dan (3) Tingkat keberlanjutan usahatani cabe merah menurut sikap para petani di Desa Sumberharjo, Kecamatan Prambanan.

\section{Kerangka Pikir}

Banyak permasalahan Usahatani Cabe Merah di daerah pinggiran kota (urban) di daerah Prambanan, baik menyangkut kondisi teknis, sosial dan ekonomi

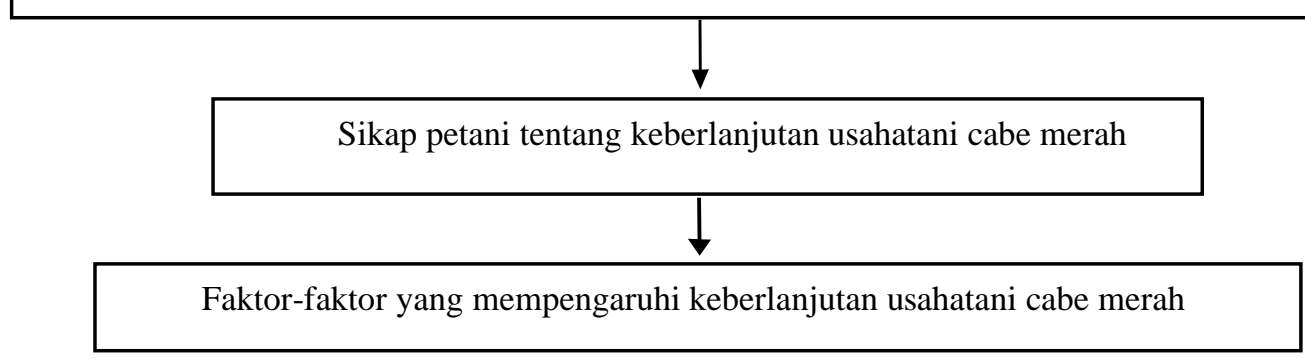

Gambar 1. Bagan kerangka pikir penelitian

\section{METODE PENELITIAN}

Penelitian ini dilakukan di Desa Sumberharjo, Kecamatan Prambanan, Kabupaten Sleman, D. I. Yogyakarta. Waktu penelitian dimulai dari bulan Agustus sampai dengan Desember 2019. Penelitian ini merupakan penelitian deskriptif kuantitatif. Menurut Nawawi (2003) metode deskriptif yaitu metodemetode penelitian yang memusatkan perhatian pada masalah- masalah atau fenomena yang bersifat aktual pada saat penelitian dilakukan, kemudian menggambarkan fakta-fakta tentang masalah yang diselidiki sebagaimana adanya diiringi dengan interpretasi yang rasional dan akurat.

Responden dalam penelitian ini adalah petani yang aktif menanam cabai merah pada musim tanam 2018/2019, berdomisili dan memiliki usahatani cabai merah di desa Sumberharjo. Pengambilan sampel petani cabai merah dilakukan secara judgement sampling dari penyuluh yang membina wilayah penelitian.Jumlah responden yang diperoleh dalam penelitian ini sebanyak 28 petani cabai merah di desa Sumberharjo, Kecamatan Prambanan.

Data penelitian diambil menggunakan metode angket. Angket yang dipakai merupakan angket tertutup dengan skala Likert meliputi empat kategori. Teknik penyebaran angket secara door to door. Selanjutnya setelah sekitar dua minggu dilakukan penarikan secara langsung door to door.

Data hasil angket kemudian dilakukan rekapitulasi dalam bentuk tabel, kemudian dilakukan pengolahan data secara deskriptif kuantitatif. Hasil pengolahan data kemudian dianalisis untuk menghasilkan rerata, jumlah dan persen, dan ditampilkan dalam bentuk tabel. Selanjutnya untuk menentukan tingkat keberlanjutan usahatani cabe merah diukur menggunakan rumus pengukuran Indeks Keberlanjutan. Skoring indikator keberlanjutan usahatani dihitung dalam bentuk Indeks Keberlanjutan, dengan mengadopsi persamaan dari pendapat 
Riduwan dan Akdon (2005) yang dirumuskan sebagai berikut.

Nilai Indeks Keberlanjutan ini akan Indeks Keberlanjutan $=\frac{\text { Skor diperoleh }}{\text { Skor maksimum }} \times 100 \%$ menunjukkan kategori tingkat keberlanjutan usahatani seperti terlihat pada Tabel 1 berikut.

Tabel 1. Kategori Tingkat Keberlanjutan Usahatani

\begin{tabular}{cc}
\hline Nilai Indeks $(\%)$ & Kategori \\
\hline $0,00-25,00$ & Buruk (tidak berkelanjutan) \\
$25,01-50,00$ & Kurang (kurang berkelanjutan) \\
$50,01-75,00$ & Cukup (cukup berkelanjutan) \\
$75,01-100,00$ & Baik (sangat berkelanjutan) \\
\hline
\end{tabular}
Sumber: Thamrin, et al. (2007)

\section{HASIL DAN PEMBAHASAN}

Hasil penelitian yang telah dilakukan dengan melibatkan 28 petani. Dengan demikian maka hasil penelitian dan pembahasannya dapat ditunjukkan sebagai berikut:

\section{Sikap Petani Terhadap Keberlanjutan Usahatani Cabe Merah}

Hasil penelitian tentang sikap petani terhadap keberlanjutan usahatani cabe merah di Kecamatan Prambanan dapat ditunjukkan pada tabel sebagai berikut:

Tabel 2. Sikap petani terhadap keberlanjutan usahatani cabe merah

\begin{tabular}{ccccc}
\hline N0. & Interval Kelas & Kategori & Jumlah & Persentase $(\%)$ \\
\hline 1 & $3,00-4,00$ & Melanjutkan & 16 & 57,14 \\
2 & $2,00-2,99$ & Ragu-ragu & 12 & 42,86 \\
3 & $1,00-1.99$ & Tidak melanjutkan & 0 & 0 \\
\hline Jumlah & & & 28 & 100 \\
\hline
\end{tabular}

Sumber: Olahan data primer (2019)

Dari Tabel 2. di atas menunjukkan bahwa jumlah petani yang mempunyai sikap melanjutkan berusahatani cabai lebih banyak (16 orang atau 57,14\%) daripada yang ragu-ragu (12 orang atau $42,86 \%$ ), sedangkan petani yang mempunyai sikap tidak melanjutkan tidak ada.

Dari hasil analisis sikap terhadap keberlanjutan berusahatani cabai merah sebagian besar petani memiliki sikap melanjutkan usahatani cabe merah, namun tidak sedikit juga yang bersikap ragu-ragu, sementara yang memiliki sikap tidak melanjutkan tidak ada. Hasil analisis sikap ini kalau dikaitkan dengan wilayah penelitian yaitu di daerah Kecamatan Prambanan yang merupakan daerah pinggiran kota yang mempunyai karakteristik antara lain (1) merupakan daerah yang rawan persaingan lahan pertanian dengan sektor lain seperti sektor properti, (2) umumnya petani sambilan. (3) irigasi yang semakin sulit. Disamping kondisi wilayah, juga sifat komoditas cabe merah merupakan komoditas yang perlu keseriusan untuk mengelolanya agar berhasil. Kondisi ini terutama bagi petani sambilan atau bagi petani kurang memadai kemampuannya akan berpikir ulang untuk berusahatani cabai merah. Dengan demikian para petani yang berusahatani cabai akan bersikap melanjutkan atau berhenti/berganti komoditas yang dirasakan lebih mudah dalam penanganannya. 
Variabel-variabel yang menjadi pertimbangan sikap petani untuk keberlanjutan berusahatani cabai merah

Dari hasil penelitian pada tabel di atas bahwa terdapat sebagian petani yang bersikap melanjutkan berusahatani cabai merah atau ada yang bersikap ragu-ragu untuk melanjutkan, maka pada penelusuran berikutnya adalah variabel-variabel apakah yang mempunyai kecenderungan mempengaruhi sikap petani tersebut. Pada hasil penelitian ini dapat ditunjukkan pada Tabel 3. sebagai berikut:

Dari tabel 3. menunjukkan indikatorindikator yang berkaitan dengan pertimbangan sikap petani terhadap keberlanjutan berusahatani cabai merah. Indikator-indikator ini meliputi sebagai berikut:

Beberapa indikator yang cenderung mempengaruhi sikap petani untuk melanjutkan berusahatani cabai merah yaitu meliputi indikator-indikator (1) Iklim yang stabil, (2) Kestabilan harga, (3) Biaya produksi terjangkau, (4) Ketersediaan tenaga kerja saat tanam dan panen, (5) Kompetensi tenaga kerja, (6) Adanya Pendampingan penyuluh, (7) Keberadaan dan keaktifan asosiasi, (8) Dukungan kebijakan pemerintah, (9) Keberadaan teknologi budidaya yang dapat diandalkan, (10) Keberadaan teknologi pengendalian OPT.(11) Ketersediaan pupuk organik, (12) Penggunaan pemupukan berimbang.

Indikator yang menyebabkan sikap petani ragu-ragu untuk melanjutkan berusahatani cabai merah adalah meliputi (1) Penurunan kesuburan tanah, (2) Curah hujan yang tinggi, (3) Kondisi rawan hama, (4) Rawan serangan penyakit patek (Antraknosa), (5) Pasar dikuasai tengkulak, (6) Kesulitan modal, (7) Keberadaan dan keaktifan poktan/gapoktan.

Indikator yang menyebabkan sikap petani cenderung tidak melanjutkan usahatani cabe merah adalah adanya Kekeringan tanah saat musim kemarau.

Variabel ekologi merupakan satusatunya variabel yang mempunyai rerata skor terendah diantara variabel lainnya. Kategori sikap pada variabel tersebut adalah ragu-ragu untuk melanjutkan usahatani cabe merah.

Indikator-indikator dari variabel ekologi hampir semua mempunyai kategori ragu-ragu, dan bahkan untuk indikator kekeringan tanah saat musim kemarau disikapi oleh petani pada kategori tidak melanjutkan usahatani cabe merah.

Tabel 3. Variabel-variabel yang menjadi pertimbangan sikap petani terhadap keberlanjutan berusahatani cabai merah

\begin{tabular}{|c|c|c|c|c|c|}
\hline No. & Variabel & Deskriptor & Indikator & $\begin{array}{l}\text { Rerata } \\
\text { Skor }\end{array}$ & Kategori \\
\hline \multirow[t]{7}{*}{1} & \multirow[t]{7}{*}{ Ekologi } & \multirow[t]{2}{*}{ Kondisi tanah } & Penurunan kesuburan tanah & 2,04 & Ragu-ragu \\
\hline & & & Kekeringan tanah saat kemarau & 1,82 & $\begin{array}{l}\text { Tidak } \\
\text { melanjutkan }\end{array}$ \\
\hline & & \multirow[t]{2}{*}{ Iklim } & Kondisi iklim yang stabil & 3,57 & Melanjutkan \\
\hline & & & Curah hujan yang tinggi & 2,18 & Ragu-ragu \\
\hline & & \multirow{2}{*}{$\begin{array}{l}\text { Hama } \\
\text { penyakit }\end{array}$} & Kondisi rawan hama & 2,79 & Ragu-ragu \\
\hline & & & $\begin{array}{l}\text { Rawan serangan penyakit patek } \\
\text { (Antraknosa) }\end{array}$ & 2,07 & Ragu-ragu \\
\hline & & Rerata & & 2,41 & Ragu-ragu \\
\hline \multirow[t]{4}{*}{2} & \multirow[t]{4}{*}{ Ekonomi } & Pasar & Pasar dikuasai tengkulak & 2,82 & Ragu-ragu \\
\hline & & Harga & Kestabilan harga & 3,54 & Melanjutkan \\
\hline & & Modal & Kesulitan modal & 2,57 & Ragu-ragu \\
\hline & & Biaya produksi & Biaya produksi terjangkau & 3,14 & Melanjutkan \\
\hline
\end{tabular}




\begin{tabular}{|c|c|c|c|c|c|}
\hline & & Rerata & & 3,02 & Melanjutkan \\
\hline \multirow[t]{4}{*}{3} & \multirow[t]{4}{*}{ Sosial } & \multirow[t]{2}{*}{ Tenaga kerja } & $\begin{array}{l}\text { Ketersediaan tenaga kerja saat } \\
\text { tanam dan panen }\end{array}$ & 3,07 & Melanjutkan \\
\hline & & & $\begin{array}{l}\text { Kompetensi tenaga kerja } \\
\text { memadai }\end{array}$ & 3,04 & Melanjutkan \\
\hline & & Penyuluh & Adanya Pendampingan penyuluh & 3,18 & Melanjutkan \\
\hline & & Rerata & & 3,10 & Melanjutkan \\
\hline \multirow[t]{4}{*}{4} & \multirow[t]{4}{*}{ Kelembagaan } & $\begin{array}{l}\text { Kelompok } \\
\text { Tani/Gapoktan }\end{array}$ & $\begin{array}{l}\text { Keberadaan dan keaktifan } \\
\text { poktan/gapoktan }\end{array}$ & 2,89 & Ragu-ragu \\
\hline & & Asosiasi & Keberadaan dan keaktifan asosiasi & 3,29 & Melanjutkan \\
\hline & & Pemerintah & Dukungan kebijakan pemerintah & 3,04 & Melanjutkan \\
\hline & & Rerata & & 3,07 & Melanjutkan \\
\hline \multirow[t]{5}{*}{5} & \multirow[t]{5}{*}{ Teknologi } & \multirow[t]{2}{*}{ Budidaya } & $\begin{array}{l}\text { Keberadaan teknologi budidaya } \\
\text { yang dapat diandalkan }\end{array}$ & 3,00 & Melanjutkan \\
\hline & & & $\begin{array}{l}\text { Keberadaan teknologi } \\
\text { pengendalian OPT }\end{array}$ & 3,00 & Melanjutkan \\
\hline & & \multirow[t]{2}{*}{ Pupuk } & Ketersediaan pupuk organik & 3,00 & Melanjutkan \\
\hline & & & $\begin{array}{l}\text { Penggunaan pemupukan } \\
\text { berimbang }\end{array}$ & 3,25 & Melanjutkan \\
\hline & & Rerata & & 3,06 & Melanjutkan \\
\hline
\end{tabular}

Sumber: Olahan data primer (2019)

Pada variabel lainnya secara umum mempunyai kategori sikap melanjutkan usahatani, walaupun pada beberapa indikator terdapat beberapa kategori sikap ragu-ragu. Variabel ekonomi dan kelembagaan mempunyai indikator dengan kategori sikap ragu- ragu yaitu pada indikator pasar yang dikuasai tengkulak dan kesulitan modal, serta keberadaan dan keaktifan kelompok tani/gapoktan.

\section{Tingkat Keberlanjutan Berusahatani Cabai Merah Menurut Sikap Petani}

Tingkat keberlanjutan usahatani cabe merah menurut sikap para petani di Desa Sumberharjo Kecamatan Prambanan diukur menggunakan indikator keberlanjutan yang diadopsi persamaan menurut Riduwan dan Akdon (2005) dapat ditunjukkan hasilnya pada Tabel 4 sebagai berikut:

Tabel 4. Indeks Keberlanjutan Usahatani Cabe Merah

\begin{tabular}{lllll}
\hline No. & Variabel & $\begin{array}{l}\text { Rerata } \\
\text { Skor }\end{array}$ & $\begin{array}{l}\text { Indeks } \\
\text { Keberlanjutan }\end{array}$ & Keputusan \\
\hline 1 & Ekologi & 2,41 & 60,24 & Cukup berkelanjutan \\
2 & Ekonomi & 3,02 & 75,50 & Sangat berkelanjutan \\
3 & Sosial & 3,10 & 77,50 & Sangat berkelanjutan \\
4 & Kelembagaan & 3,07 & 76,75 & Sangat berkelanjutan \\
5 & Teknologi & 3,06 & 76,50 & Sangat berkelanjutan \\
\hline & Keseluruhan & 2,86 & 71,50 & Cukup berkelanjutan
\end{tabular}

Sumber: Olahan data primer (2019)

Dari Tabel 4. di atas menunjukkan tingkat keberlanjutan usahatani cabe merah di Desa Sumberharjo sebagian besar dari variabel pada kategori Sangat berkelanjutan, kecuali variable ekologi pada kategori cukup berkelanjutan, dan secara keseluruhan pada kategori cukup berkelanjutan. Hal ini mengindikasikan bahwa variabel ekologi perlu diperhatikan, dan perlu dibenahi secara serius agar 
usahatani cabe dapat berkelanjutan.

Nilai indeks keberlanjutan tertinggi pada variabel Sosial dengan nilai indeks keberlanjutan sebesar 77,50. Hal ini sesuai dengan hasil penelitian I Nyoman Gede Ustriyana \& Ni Wayan Putu Artini (2018), bahwa Hasil perhitungan indeks keberlanjutan untuk 30 variabel yang masuk katagori "tinggi" atau yang memiliki nilai indeks $\geq 0.68$ hanya 1 dan berasal dari dimensi sosial.

\section{SIMPULAN DAN SARAN}

Sebagian besar petani di Desa Sumberharjo, Kecamatan Prambanan memiliki sikap ingin melanjutkan usahatani cabe merah, dan terdapat sebagian yang ragu-ragu untuk melanjutkan usahatani cabe merah. Variabel-variabel yang meliputi faktor ekonomi, faktor sosial, faktor kelembagaan dan faktor teknologi direspon atau disikapi sebagai pendorong untuk melanjutkan usahatani cabe merah, sementara variabel ekologi disikapi raguragu untuk melanjutkan usahatani tersebut.

Tingkat keberlanjutan usahatani cabe merah yang diukur menggunakan indeks keberlanjutan usahatani memberikan keputusan sangat berkelanjutan sebagian besar variabel, kecuali variable ekologi, tetapi secara keseluruhan memberi keputusan cukup berkelanjutan.

Dari hasil penelitian ini dapat mengimplikasikan bahwa sebagian petani masih ada yang merasa ragu-ragu untuk melanjutkan usahatani cabe merah, karena terdapat beberapa masalah yang perlu dibenahi. Masalah yang perlu dipertimbangkan secara serius untuk dibenahi yaitu masalah ekologi yang mempengaruhi keberhasilan usahatani cabe merah, terutama pada indikator kekeringan saat musim kemarau. Dengan demikian maka pihak yang terkait dengan irigasi untuk menindaklanjuti hal tersebut, sehingga masalah irigasi khususnya pada musim kemarau dapat diatasi.

\section{PUSTAKA ACUAN}

Alimul Hidayat, A. Aziz. (2010). Metode Penelitian Keperawatan dan Teknik Analisa Data. Jakarta : Salemba Medika

Azwar, S. (2000). Sikap Manusia, Teori dan Pengukurannya. Yogyakarta: Pustaka Pelajar Jogja Offset.

Azwar, S. (2005). Sikap Manusia, Teori dan Pengukurannya. Yogyakarta: Pustaka Pelajar Jogja Offset.

Bhossaq MR, Afzalinia F, Moradi H. (2012). Measuring indicators and determining factors affecting sustainable agricultural development in rural areas - a case study of Ravansar, Iran. International Journal of AgriScience Vol 2(6): 550-557. June 2012

Heri Purwanto. (1998). Pengantar Perilaku Manusia. Jakarta: EGC.

I Nyoman Gede Ustriyana \& Ni Wayan Putu Artini, (2018). Analisis Indeks Keberlanjutan Usahatani Cabe Merah di Kabupaten Bangli. Jurnal SosialEkonomi Pertanian dan Agribisnis SOCA Vol.12 No.1 Desember 2018. Diakses dari SOCA: Jurnal Sosial Ekonomi Pertanian (unud.ac.id) pada tanggal 30 Maret 2021.

Kang Toery. (2017). Faktor Pendukung Sukses Budidaya Cabe. Diakses dari http://www.kangtury. com/2017/01/ faktor-pendukung-sukses-budidayacabe.html pada Tanggal 8-2-2020 Pk. 16.54

Kay, D. \& Alder, J. (1999). Coastal planning and management. New York: Routledge.

Lisa Tri Kurnia, Rosyani, dan Aulia Farida. (2018). Faktor-Faktor Yang Mempengaruhi Keberlanjutan Petani Berusahatani Padi Sawah (Studi Kasus di Desa Pulau Aro Kecamatan Tabir 
Ulu Kabupaten Merangin). Diakses dari https://repository.unja. ac.id/3914/1/ D1B013078_LISA\% 20TRI\%20KURNIA_JURNAL.pdf pada tanggal 25 November 2019 pukul 16.14

Nawawi. (2003). Metode Penelitian Bidang Sosial. Yogyakarta: Gadjah Mada University Press.

Novita, E., Suryaningrat, Andriani, I., \& Widyotomo, S. (2012). Analisis keberlanjutan kawasan usaha perkebunan kopi (KUPK) rakyat di Desa Sidomulyo Kabupaten Jember. Jurnal Teknologi Pertanian Agritech, 32(2), 126-135.

OECD. (1993). Coastal zone management. integrated policies. Organization for Economic Cooperation and Development. Paris.

Rao NH, Rogers PP. (2006). Assessment of agriculture sustainability. Current
Science, Vol. 91, No.4: 439-448.

Riduwan dan Akdon (2005). Rumus dan Data Dalam Aplikasi Statistik. Bandung: Alfabeta.

Notoatmodjo, S. (1997). Pendidikan dan Perilaku Kesehatan Dalam Ilmu Kesehatan Masyarakat. Jakarta: Rineka Cipta.

Notoatmodjo, S. (2003). Pendidikan dan Perilaku Kesehatan. Jakarta: Rineka Cipta.

Thamrin, S. H. Sutjahjo, C. Herison dan S. Sabiham. (2007). Analisis Keberlanjutan Wilayah Perbatasan Kalimantan Barat Malaysia untuk Pengembangan Kawasan Agropolitan. Jurnal Agro Ekonomi (JAE) Volume 25 Nomor 2. Oktober 2007. Badan Penelitian Pengembangan Pertanian Departemen Pertanian. Jakarta. pp. 103- 124.

DOI : 